\title{
ESTIMATION OF URBAN WASTE GENERATED AND UNCOLLECTED IN ROMANIA
}

\author{
Mihai Florin - Constantin*, Ghiurcă Andreea, Lămăşanu Andreea \\ * "Alexandru Ioan Cuza“ University, Faculty of Geography and Geology, Carol I Avenue, no. \\ 20 A, 700505, Iasi, Romania, e-mail: mihai.florin86@yahoo.com
}

\begin{abstract}
Urban waste generation due to economic development and living standards raise serious problems in providing sustainable waste management of cities. Because not all of Romania's urban population are served by sanitation services, some wastes are generated and uncollected being often uncontrolled disposed contributing to urban pollution. This paper aims on the one hand one to estimate the amount of urban waste generated and uncollected and on the other hand to perform a spatial analysis of these wastes at the Romanian counties level using thematic cartography. Outlined regional disparities allows a more accurate assessment of the vulnerability of cities to waste pollution. Total urban population access to waste collection services is a basic condition for developing an efficient waste management system and to reduce pollution. The current urban waste management system must improve to comply objectives and targets imposed by the EU acquis.
\end{abstract}

Key words: waste generation,sanitation services, urban areas, uncontrolled disposal.

\section{INTRODUCTION}

Lifestyles due to growth of population welfare generate an increasingly household solid waste .( Humă,2003).Thus solid waste management is one of the most challenging issues in urban cities, which are facing a serious pollution problem (Kumar et al.,2009).Furthermore, most urban wastes are still disposed into landfills which have a finite capacity and were originally located relatively close to the urban areas (Guariso et al., 2009).

Urban population access to sanitation services is still not entirely in the new member states of EU (OECD,2008) leading to uncontrolled waste disposal in urban areas. In the past few decades, solid waste management systems in Europe adopted various economic, regulatory or incentive based instruments(Pires et al.,2011;Husaini et al.,2007).The current waste definitions at the European level are not satisfactory and will not lead toward sustainable waste management (Pongrácz,2004). It is definitive that in the next decades, cities are going to be the main generators of urban and hazardous wastes ( Rojas et al.,2009). As science and technology developed, the management of an ever increasing volume of waste became a very organised, specialized and complex activity.(Giusti,2009)

Efficient municipal solid waste management systems require professional management, supported by an informed population and appropriate legislation and policies(Wilson et al.,2001). 


\section{MATERIALS AND METHODS}

Statistics on urban population access to sanitation services are analyzed from a geographic point of view using thematic cartography. Article is considering a comparative analysis for 2003 and 2008 to reveal the changes in context of Romania's EU accession. It has been created a statistical database on the number of urban population unserved by sanitation services for the Romanian counties.Data on waste production, recycling and disposal are essential for designing routes and collection systems, determining placements for bins and managing collection crews. (Chowdhury,2009).

Due to the lack of coherent and relevant data on the amount of urban waste generated at county level, it has been used an average indicator of urban waste generation. In Romania, the limits of solid waste generation indicator is between 0.78 and $1.03 \mathrm{~kg} /$ inhabitant / day in urban areas (Bularda et al., 1992).Between 1994-2005 domestic waste generation indicator has an average of $0.8 \mathrm{~kg} /$ inhabitant/day (Antonescu,2006).Taking into account the economic growth in the period 2003-2008 that led to an increase in consumption,this indicator has been assigned different values for the undergoing study years respectively: $0.85 \mathrm{~kg} /$ inhabitant / day for 2003 and $0.9 \mathrm{~kg} /$ inhabitant / day for 2009. Thus by multiplying the number of unserved urban population by sanitation services with average indicator of waste generation are obtained quantities of urban waste generated and uncollected in the counties of Romania. No such calculations were made for the city of Bucharest and Ilfov county because of incomplete data. Uncollected urban waste is generally uncontrolled disposed on peripheral areas damaging various environmental factors and urban landscape.Their mapping using the method of proportional circles correlated to the percentage of urban population served by waste collection services allow an analysis of territorial disparities in Romania as well as identifying urban population vulnerable to waste pollution .

\section{RESULTS AND DISCUSSION}

Level of economic development and urban population density influences the generation of municipal waste in a country (Rajeev et al.,2011).In Romania, uncontrolled waste disposal in urban areas is due to limited access to sanitation services. Uncontrolled waste is made, especially by people with modest incomes who have not signed contracts with the

operators of sanitation (Humă and Chiriac ,2003) .Traditional collection of household and similar waste in the mixture, is the most common, accounting for a share of about 97\% (Oroian et al.2009). Both urban and rural areas, the waste problem is insufficiently solved in terms of disposal, recycling or 
treatment (Ungureanu ,2005). Because of the lack of weighing systems of waste, the estimation of waste quantities generated or disposed has a high percentage of miscalculation ( Gavrilescu ,2007).

In 2003 first map (fig.1) shows that the urban population is partially served by sanitation services, only 8 counties and Bucharest have a rate of over $92 \%$ of the population covered by waste collection services unlike the Teleorman,Suceava,Vrancea, and Buzău counties, where access is limited to sanitation services (only 61-69\%).

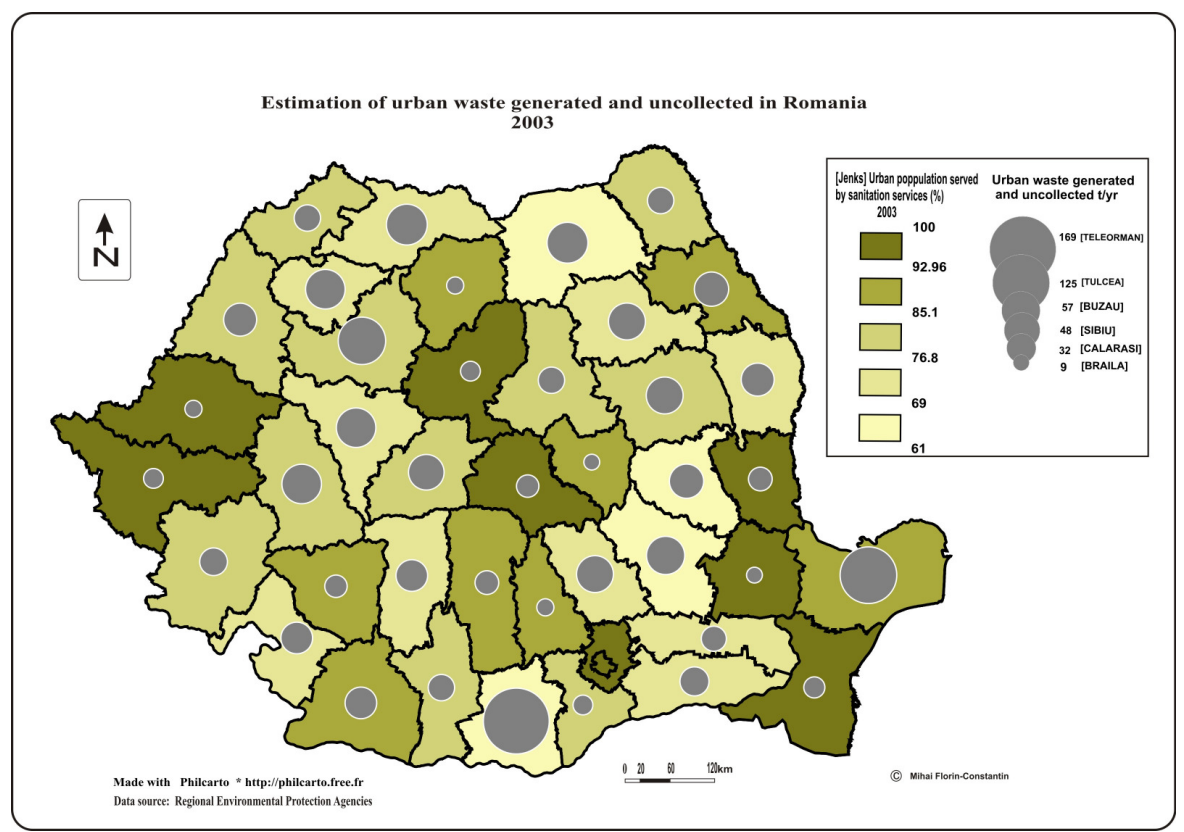

Fig. 1. Spatial analysis of urban waste generated and uncollected in 2003

In this context, the vulnerability to uncontrolled urban waste disposal is high and environmental factors are affected differently depending on the geographic location of urban settlements. Proximity to rivers, especially in mountainous or subcarpathian regions of urban settlements in terms of rudimentary waste collection facilities lead to pollution of rivers. In regions of hill and plain, uncontrolled waste disposal take place in the form of illegal landfills usually located in the peripheral areas of cities or working-class neighborhoods.These areas insalubrious becomes hotbeds of infections and represent a real risk to the human health. Generally the lack of waste treatment facilities increase the frequency of their illegal landfills.(Ichinose and Yamamoto,2011). In Romania is a weak, old and outdated technical equipment for waste management which does not comply demands for a modern activity.( Bold and Mărăcineanu, 
2003) However, with EU funds it have been implemented integrated solid waste management systems (eg Piatra Neamţ)

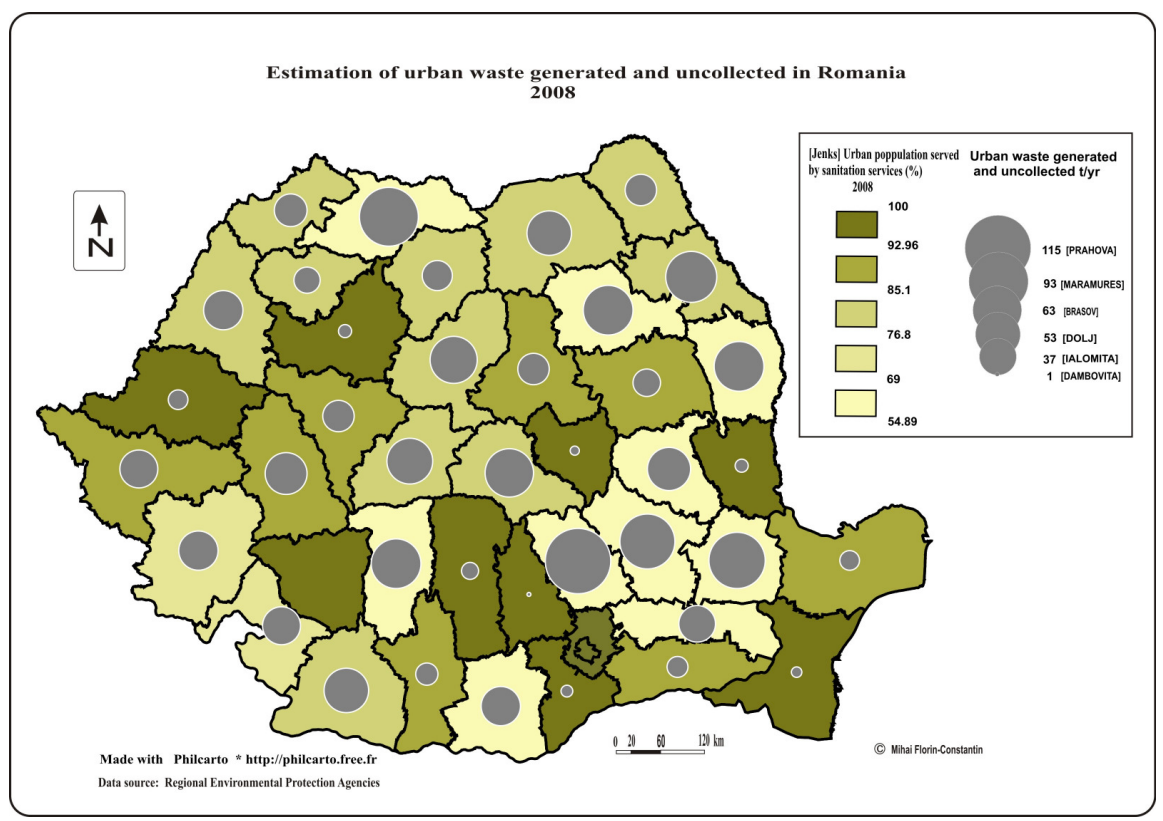

Fig. 2 Spatial analysis of urban waste generated and uncollected in 2008

Unlike 2003, in 2008 the amount of waste generated and uncollected is higher. This is explained by the fact that in 2004-2006 more rural localities (often without waste management facilities ) have been declared cities leading to a decrease in the percentage of urban population served to sanitation services.Also since 2003 it has implemented a new system of collecting statistical data from sanitation operators, data for 2008 being more reliable. Major negative changes are identified in the counties of Brăila ,Maramureş, Mureş, Vâlcea and Prahova consisting of a lower percentage of urban population served by sanitation services leading to increasing quantities of waste generated and uncollected. The vulnerability of urban areas to uncontrolled waste disposal in these counties is high , an average of $30 \%$ urban population lacks sanitation services. It also increases the amount of urban waste uncollected compared to 2003, being recorded in the following counties : Buzău, Iaşi, Caraş-Severin Timiş, Dolj and Neamţ . This fact confirms that urban waste management is still an important environmental issue in these regions. 


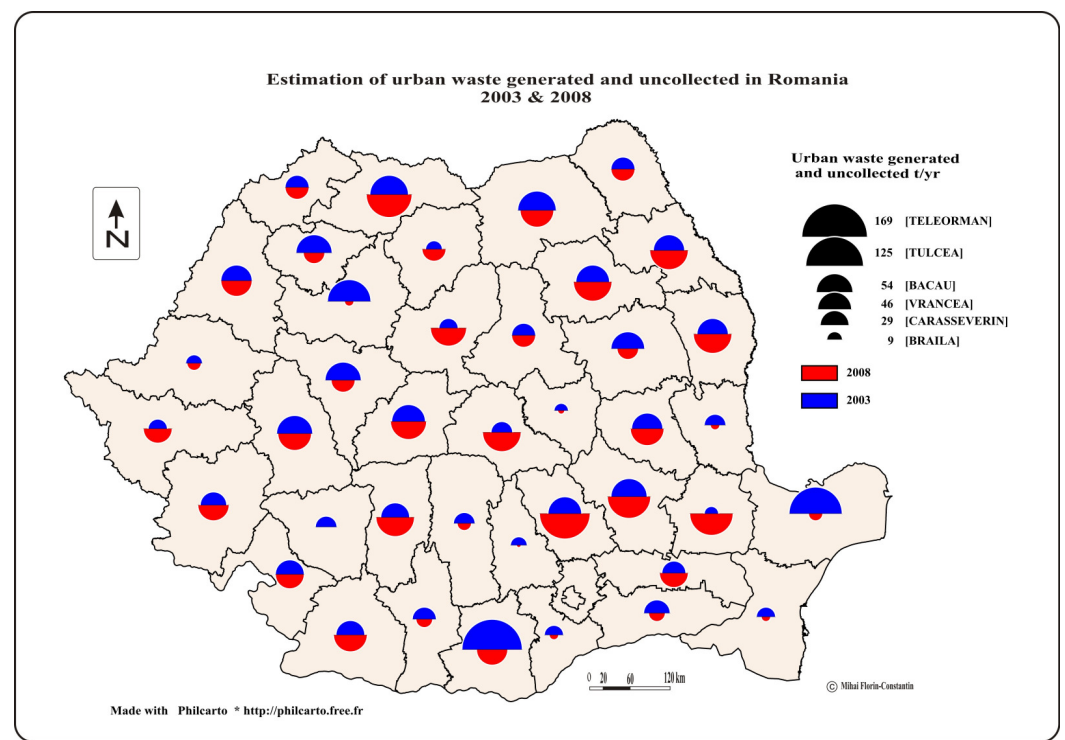

Fig. 3 A comparative analysis of uncollected urban waste 2003 vs 2008

Insignificant changes or constantly situations are found in Arad, Mehedinți, Botoşani, Satu Mare and Harghita counties ,that denote the lack of effective measures to improve urban waste management. Positive evolutions through an increasing share of urban population served by sanitation services and significant decreases of uncollected urban waste is distinguished for the following counties :Cluj, Tulcea, Constanta and Giurgiu. Uncontrolled urban waste disposal is insignificant in counties Gorj, Argeş, Galați and Covasna, because the high share of population to sanitation services.

\section{CONCLUSIONS}

Partially access of the urban population to sanitation services lead to uncontrolled waste disposal with complex implications on the environment. Estimation of the amount of waste generated and uncollected allows an assessment of vulnerability to uncontrolled urban waste disposal.Analysis of disparities in Romania using thematic cartography reveals the existing dysfunctions in the current system of urban waste management.

Implementation of the EU acquis require improvements for waste management facilities and full coverage of urban population to sanitation services.

\section{Acknowledgements}

This work was supported by the the European Social Fund in Romania, under the responsibility of the Managing Authority for the Sectoral Operational Programme for Human Resources Development 2007-2013 [grant POSDRU/CPP 107/DMI 1.5/S/78342]. 


\section{REFERENCES}

1. Antonescu, N., 2006,Gestiunea şi tratarea deşeurilor urbane -gestiune regională , Edit.Matrix Rom,Bucureşti .

2. Bold,O.V., G.A. Mărăcineanu, 2003,Managementul deşeurilor solide urbane şi industrial,,Edit.Matrix Rom,Bucureşti .

3. Bularda,G., D.C. Bularda, T. Catrinescu, 1992,Reziduuri menajere,stradale si industriale,Edit. Tehnica,Bucuresti.

4. Chiriac., D, C. Humă, 2007, Impactul serviciilor de salubritate din România asupra condițiilor de habitat şi a calității vieții - Studiu de caz: Municipiul Bucureşti,Calitatea Vietii, nr 3-4,2007, 283-306.

5. Chowdhury M., 2009, Searching quality data for municipal solid waste planning, Waste Management, 29, 2240-2247.

6. Gavrilescu,C.,2007, Current problems in the management of urban waste in Botosani city ,Present environment and sustainable development, 1, 249-254.

7.Giusti, L., 2009, A review of waste management practices and their impact on human health, Waste Management, 29, 2227-2239.

8. Guariso G., F. Michetti, F. Porta , S. Moore ,2009, Modelling the upgrade of an urban waste disposal system , Environmental Modelling \& Software, 24 ,2009,1314-1322.

9 Humă, C., D. Chiriac ,2006, Aspecte globale ale ecologizării urbane şi implicaţii asupra calității vieții, Calitatea vieții, 14, nr. 1, 1-16.

10. Husaini I.G., A. Garg , K.H. Kimb, J. Marchant , S.J.T. Pollard , R. Smith ,2007, European household waste management schemes: Their effectiveness and applicability in England, Resources, Conservation and Recycling ,51 , 248-263.

11. Ichinose, D., M. Yamamoto, 2011 - On the relationship between the provision of waste management service and illegal dumping, Resource and Energy Economics ,33 ,79-93.

12. Kumar S., J.K.. Bhattacharyya, A.N. Vaidya , T. Chakrabarti, , S. Devotta, A.B. Akolkar ,2009, Assessment of the status of municipal solid waste management in metro cities, state capitals, class I cities, and class II towns in India: An insight, Waste Management ,29, 883-895.

13. OECD ,2008, Environmental Data ,Compedium 2006-2008, Waste chapter.

14. Oroian I.,, A. Odagiu, I. Brasovean, P. Burduhos ,2009, The Waste Management in Romania. A Case Study: WMS Implementation, ProEnvironment ,2 ,145 - 151.

15. Pires A., G. Martinho, Ni-Bin Chang ,2011,Solid waste management in European countries: A review of systems analysis techniques ,Journal of Environmental Management $92,1033-1050$.

16. Pongrácz, E., V. J. Pohjola,2004, Re-defining waste, the concept of ownership and the role of waste management ,Resources, Conservation and Recycling, 40, 141-153.

17.Rojas,C.R.I.,C.E.A.,Zambrano,2008,Urban observatories opportunities for environmental monitoring: Solid wastes ,Waste Management ,28, 540-544.

18 .Singh R.P., P. Singh, A.S.F. Araujo, M. H. Ibrahim, O. Sulaiman,2011, Management of urban solid waste: Vermicomposting a sustainable option, Resources, Conservation and Recycling ,55 , 719-729.

19. Ungureanu B.I., 2005, Geografia Mediului ,Edit . Universită $\square$ ii “Alexandru.Ioan Cuza" ,Iaşi.

20. Wilson E.J., F.R. McDougall, J. Willmore,2001, Euro-trash: searching Europe for a more sustainable approach to waste management, Resources, Conservation and Recycling ,31, 327-346. 